DOI 10.22460/jpmi.v1i3.219-228

\title{
KEMAMPUAN PEMECAHAN MASALAH MATEMATIS SISWA SMP PADA MATERI PELUANG DENGAN PENDEKATAN KONTEKSTUAL
}

\author{
Putri Tasya Monica $^{1}$, M. Afrilianto ${ }^{2}$, Euis Eti Rohaeti ${ }^{3}$ \\ ${ }^{1,2,3}$ IKIP Siliwangi, Jl. Terusan Jenderal Sudirman, Cimahi, Jawa Barat, Indonesia \\ ${ }^{1}$ putrimonicatasya@gmail.com, ${ }^{2}$ muhammadafrilianto1@ikipsiliwangi.ac.id, \\ 3e2rht@ikipsiliwangi.ac.id
}

Diterima: 10 Maret 2018; Disetujui: 28 Mei 2018

\begin{abstract}
This type of research is a classroom action research. This study aims to examine the improvement of mathematical problem solving ability of junior high school students on the opportunity material. This research was conducted on the students of class IX-C SMP Mahardhika Batujajar academic year 2017/2018 with the number of students 34 people. The instruments used are cycles I and II (after giving of action); and an observation sheet on teachers and students for the conditions of action implementation. The procedures of this study consist of: (1) Planning, (2) Implementation of action, (3) Observation and evaluation, and (4) Reflection. The results showed that students' mathematical problem solving ability in the subject matter could be improved through contextual approach.
\end{abstract}

Keywords: Mathematical Problem Solving, Opportunity, Contextual Approach

\begin{abstract}
Abstrak
Jenis penelitian ini adalah penelitian tindakan kelas. Penelitian ini bertujuan untuk menelaah peningkatan kemampuan pemecahan masalah matematis siswa SMP pada materi peluang. Penelitian ini dilaksanakan pada siswa kelas IX-C SMP Mahardhika Batujajar tahun pelajaran 2017/2018 dengan jumlah siswa 34 orang. Instrumen yang digunakan adalah tes siklus I dan II (setelah pemberian tindakan); dan lembar observasi terhadap guru dan siswa untuk kondisi pelaksanaan tindakan. Prosedur penelitian ini terdiri dari: (1) Perencanaan, (2) Pelaksanaan tindakan, (3) Observasi dan evaluasi, dan (4) Refleksi. Hasil penelitian menujukkan bahwa kemampuan pemecahan masalah matematis siswa SMP pada materi peluang dapat ditingkatkan melalui pendekatan kontekstual.
\end{abstract}

Kata Kunci: Pemecahan Masalah Matematis, Peluang, Pendekatan Kontekstual

How to cite: Monica, P. T., Afrilianto, M., \& Rohaeti, E. E. (2018). Kemampuan Pemecahan Masalah Matematis Siswa SMP pada Materi Peluang dengan Pendekatan Kontekstual. JPMI - Jurnal Pembelajaran Matematika Inovatif, 1 (3), 219-228.

\section{PENDAHULUAN}

Salah satu tujuan umum pendidikan matematika ditekankan pada siswa untuk memiliki aspek memecahkan masalah yang meliputi kemampuan memahami masalah, merancang model matematika, menyelesaikan model dan menafsirkan solusi yang diperoleh (Minarni, 2012). Dari pengalaman yang terlihat, banyak siswa yang beranggapan bahwa matematika adalah pelajaran yang sulit. Hal ini tentu berpengaruh pula dalam proses pembelajaran matematika. Selain itu, Suhena (Minarni, 2012) juga menyatakan bahwa "temuan lain berdasarkan hasil wawancara dengan 30 guru matematika di sekolah menengah pertama (SMP) adalah masih 
banyak siswa yang mengalami kesulitan dalam belajar matematika terutama ketika memecahkan soal-soal yang berbentuk cerita (masalah)".

Dikarenakan rendahnya kemampuan pemecahan masalah matematis, diperlukan adanya perubahan dalam kegiatan pembelajaran, sehingga pembelajaran dapat berjalan lebih menyenangkan dan bermakna bagi siswa. Ini dikarenakan kemampuan pemecahan masalah merupakan salah satu aspek yang harus dimiliki siswa untuk menunjang pembelajaran matematika (Dahlia, 2016).

Oleh karena itu, kemampuan pemecahan masalah matematis siswa harus ditingkatkan dengan memberikan pembelajaran secara bermakna kepada siswa (Hidayat \& Sariningsih, 2018; Mulhamah dan Putrawangsa, 2016). Bila kita menginginkan siswa belajar dengan secara bermakna, tahap pengajaran kita supaya disesuaikan dengan tahap berfikir siswa. Pembelajaran yang disesuaikan dengan tingkat berpikir siswa menurut penulis salah satunya adalah pembelajaran yang mengaitkan dengan permasalahan keseharian siswa.

Dari permasalahan di atas, penulis tertarik untuk melakukan penelitian menggunakan pendekatan pembelajaran yang membuat siswa menjadi tertarik dan lebih paham dalam belajar matematika sebagai solusi untuk meningkatkan kemampuan pemecahan masalah matematis siswa, salah satu dari pendekatan itu adalah pendekatan kontekstual.

\section{METODE}

Jenis penelitian ini yaitu penelitian tindakan kelas. Penelitian tindakan kelas ini terdiri dari dua siklus, setiap siklus terdiri dari perencanaan, tindakan, pengamatan, dan refleksi. Penelitian ini dilakukan di Kelas IX-C SMP Mahardhika Batujajar dengan materi Peluang. Siklus dihentikan jika pembelajaran matematika dengan pendekatan pembelajaran kontekstual yang telah dilakukan sesuai dengan indikator keberhasilan penelitian, yaitu meningkatnya kemampuan pemecahan masalah siswa. Indikator tercapainya peningkatan kemampuan pemecahan masalah matematis siswa (Mulhamah dan Putrawangsa, 2016) pada penelitian ini merujuk pada:

a. Adanya pencapaian ketuntasan belajar minimal $75 \%$ dari jumlah seluruh siswa dan perolehan nilai minimal sesuai KKM tempat penelitian.

b. Peningkatan kemampuan pemecahan masalah siswa diperoleh dari pendeskripsian lembar aktivitas siswa dan penilaian sesuai dengan rubrik penskoran dan nilai akhir di analisis mengikuti poin pertama.

c. Peningkatan kreativitas siswa dilihat dari skor yang diperoleh pada lembar observasi siswa dalam menyelesaikan masalah matematika dalam pembelajaran dikelas.

\section{HASIL DAN PEMBAHASAN}

\section{Hasil}

\section{Tindakan Siklus 1}

\section{Perencanaan}

Setelah ditetapkan untuk menerapkan pendekatan pembelajaran kontekstual untuk meningkatkan pemecahan masalah matematis siswa maka kegiatan selanjutnya menyiapkan beberapa hal yang diperlukan selama pelaksanaan tindakan. Peneliti bersama guru melakukan 
pembentukan kelompok yang disesuaikan dengan pendekatan pembelajaran kontekstual. Karena jumlah siswa kelas IX-C SMP Mahardhika Batujajar sebanyak 34 orang, maka kelompok yang dibentuk sebanyak 5 kelompok, dengan 4 kelompok terdiri dari 7 orang dan 1 kelompok terdiri dari 6 orang. Dalam setiap kelompok terdiri dari campuran siswa laki-laki dan perempuan yang memiliki kemampuan (tinggi, sedang, rendah).

Selanjutnya, peneliti melakukan hal-hal sebagai berikut:

a. Pembuatan rencana pelaksanaan pembelajaran (RPP) dengan menggunakan pendekatan pembelajaran kontekstual,

b. Menyiapkan lembar observasi yang ditujukan pada guru dan siswa (aspek yang diobservasi didasarkan pada langkah-langkah pembelajaran pada RPP),

c. Menyiapkan LKS,

d. Merancang perangkat evaluasi untuk tes siklus I

e. Persiapan lainnya adalah lebih memantapkan pengetahuan dan pemahaman guru mengenai pelaksanaan pembelajaran dengan pendekatan pembelajaran kontekstual.

\section{Pelaksanaan Tindakan}

Tindakan pembelajaran siklus I dilaksanakan dalam dua kali pertemuan (4 jam pembelajaran) yaitu pada jam 07.20-10.00 hari rabu tanggal 15 November 2017. Dalam hal ini, pelaksanaan penelitian tindakan kelas dilakukan oleh peneliti, sedangkan teman sejawat bertindak sebagai pengamat (observer).

Kegiatan pembelajaran diawali dengan pembukaan yang dilakukan oleh guru dengan mengucapkan salam dan seharusnya guru menyiapkan siswa untuk mengikuti pembelajaran pada materi yang akan dipelajari serta menyampaikan tujuan pelajaran yang akan dicapai pada pertemuan hari itu, tapi hal itu tidak dilakukan oleh guru. Selanjutnya, dengan metode pengelompokan siswa dan penemuan terbimbing guru memberikan motivasi kepada siswa dengan menjelaskan pentingnya mempelajari konsep konsep peluang dalam kehidupan seharihari dengan memberitahu bahwa konsep peluang sangat erat hubungannya dalam kehidupan sehari-hari.

Kemudian guru mengadakan apersepsi yaitu mengaitkan konsep awal yang telah dimiliki siswa dengan materi pembelajaran yang akan dipelajari. Dalam kegiatan kelompok, guru membagikan LKS kepada masing masing kelompok dan meminta kepada setiap kelompok untuk berdiskusi dan saling membagi tugas dalam menyelesaikan soal-soal yang diberikan. Guru memantau dan memberikan bimbingan terhadap kegiatan diskusi tersebut. Setelah waktu yang diberikan untuk diskusi kelompok selesai, guru meminta perwakilan dari setiap kelompok untuk mempresentasikan hasil diskusinya. Diakhir pembelajaran guru memberikan tes berupa soal pemecahan masalah mengenai menentukan titik sampel dan ruang sampel. Selama proses pembelajaran berlangsung observer mengobservasi jalannya pembelajaran dengan menggunakan lembar observasi guru dan siswa.

\section{Observasi dan Evaluasi}

Pada setiap pertemuan, pengamatan dilakukan sejak awal sampai akhir pembelajaran menggunakan lembar observasi. Setiap aspek yang diamati disusun mengacu pada RPP dan ditujukan terhadap guru model dan siswa kelas IX-C SMP Mahardhika Batujajar. 


\section{Observasi}

Berdasarkan hasil lembar observasi aktivitas guru, ketuntasan hasil observasi guru pada proses pembelajaran mencapai 70,76\%. Hal ini menunjukkan bahwa indikator kinerja dari segi proses belum tercapai yaitu minimal $75 \%$ proses pelaksanaan tindakan dilaksanakan sesuai dengan rencana pelaksanaan pembelajaran yang ditetapkan sehingga perlu dilakukan perbaikan pada siklus berikutnya.

Sementara itu, berdasarkan hasil lembar observasi aktivitas siswa, ketuntasan hasil observasi siswa pada proses pembelajaran mencapai 58\%. Hal ini menunjukkan bahwa indikator kinerja dari segi proses belum tercapai yaitu minimal $75 \%$ proses pelaksanaan tindakan dilaksanakan sesuai dengan rencana pelaksanaan pembelajaran yang ditetapkan sehingga perlu dilakukan perbaikan pada siklus berikutnya.

\section{Evaluasi}

Setelah dilakukan pembelajaran sebanyak 2 kali pertemuan dalam 1 hari untuk menyelesaikan kompetensi dasar "menentukan ruang sampel suatu percobaan" yang merupakan penjabaran dari standar kompetensi "memahami peluang kejadian sederhana", dilaksanakan evaluasi dengan sebutan tes siklus I pada hari yang sama yaitu hari Rabu, 15 November 2017. Kegiatan ini dilakukan untuk mengetahui sejauh mana penguasaan pemecahan masalah matematis siswa pada materi "peluang" setelah dilakukan pembelajaran dengan pendekatan kontekstual.

Hasil tes menunjukkan bahwa masih sedikit siswa yang mampu menunjukkan kemampuan pemecahan masalah matematis. Hasil tes ini juga menunjukkan penguasaan siswa secara klasikal terhadap materi pelajaran. Karena belum secara keseluruhan siswa dapat menguasainya, maka diperlukannya penambahan tindakan agar siswa dapat betul-betul memahami materi peluang ini.

Tabel 1. Hasil Analisis Ketuntasan Belajar pada Pembelajaran Siklus I

\begin{tabular}{llcc}
\hline No. & Ketuntasan & Jumlah & Persentase (\%) \\
\hline $1 . \quad$ Tuntas & 15 & 50 \\
\hline $2 . \quad$ Tidak tuntas & 15 & 50 \\
\hline Jumlah siswa & 30 & \\
\hline Rata-rata nilai & 55,16 & 100 \\
\hline Persentasi Ketuntasan & & \\
\hline
\end{tabular}

Berdasarkan tabel di atas, dengan melihat skor yang diperoleh siswa dari soal-soal yang diberikan pada tes siklus I ini, diperoleh 15 siswa yang mampu memperoleh nilai 75 ke atas atau hanya 50\% dari 30 siswa yang hadir yang mampu mencapai kriteria ketuntasan minimal (KKM). Hal ini menunjukkan kemampuan pemecahan masalah matematis siswa sudah cukup baik. Namun terdapat 15 siswa yang memperoleh nilai dibawah 75 atau sekitar $50 \%$ siswa yang tidak dapat mencapai kriteria ketuntasan minimal (KKM). Hal ini menunjukan bahwa indikator kerja dari segi hasil belum tercapai sehingga perlu dilakukan perbaikan pada siklus berikutnya. 


\section{Refleksi}

Pada tahap ini, peneliti dan guru beserta observer bersama-sama menilai dan mendiskusikan kelemahan-kelemahan yang terdapat pada pelaksanaan tindakan siklus I yang akan diperbaiki pada siklus II. Pada siklus I ini, penerapan pendekatan kontekstual masih belum optimal. Hal ini dapat dilihat dari rata-rata ketuntasan skenario pembelajaran yang dilaksanakan oleh guru hanya mencapai 70,76\%. Beberapa kelemahan tersebut antara lain:

a. Guru harus menyampaikan tujuan pembelajaran agar siswa memiliki gambaran yang jelas tentang pengetahuan yang diperoleh setelah proses pembelajaran,

b. Guru harus memberikan pemahaman kepada siswa tentang manfaat dan tujuan belajar secara berkelompok,

c. Guru harus lebih memberikan bimbingan terhadap kelompok yang memerlukan bimbingan agar waktu yang digunakan lebih efektif,

d. Siswa harus belajar saling menghargai dan menerima pendapat temannya agar dapat terjalin kerjasama yang baik dalam kelompok,

e. Siswa harus berani bertanya ketika terdapat kesulitan dalam belajarnya, tidak hanya pada siswa tertentu saja,

f. Siswa harus belajar dengan tekun agar hasil belajarnya dapat memenuhi ketuntasan belajar yang telah ditetapkan.

\section{Tindakan Siklus II}

\section{Perencanaan}

Berdasarkan hasil observasi, evaluasi dan refleksi pada tindakan siklus I, maka peneliti bersama guru merencanakan tindakan siklus II, agar kelemahan-kelemahan yang terjadi pada pelaksanaan tindakan siklus I dapat diperbaiki dan mencapai hasil yang maksimal.

Selanjutnya, pada tahap perencanaan ini peneliti berkolaborasi dengan guru melakukan hal sebagai berikut:

a. Membuat rencana perbaikan pembelajaran (RPP) untuk tindakan siklus II.

b. Membuat lembar observasi yang ditujukan pada guru dan siswa (aspek yang diobservasi didasarkan pada langkah-langkah pembelajaran pada RPP)

c. Menyiapkan perangkat pembelajaran yang diperlukan seperti membuat Lembar Kerja Siswa (LKS)

d. Menyiapkan perangkat evaluasi untuk evaluasi tindakan siklus II.

\section{Pelaksanaan Tindakan}

Pelaksanaan tindakan siklus II terdiri dari 2 pertemuan yang dilaksanakan pada 1 hari yang sama ,yaitu pada hari Rabu, 22 November 2017 yang dilaksanakan pada pukul 07.20-10.00. Dalam hal ini, pelaksanaan penelitian tindakan kelas dilakukan oleh peneliti, sedangkan teman sejawat bertindak sebagai pengamat (observer) sama seperti yang dilakukan pada pelaksanaan tindakan siklus I. Sebagai gambaran kegiatan pembelajaran diawali dengan pembukaan yang dilakukan guru dengan mengucapkan salam, menyampaikan tujuan pembelajaran, memberi motivasi kepada siswa tentang pentingnya materi peluang dalam kehidupan sehari-hari dan mengadakan apersepsi untuk menggali pengetahuan yang dimiliki 
siswa tentang peluang, serta kilas balik dari materi yang telah dipelajari mengenai kompetensi dasar "menentukan ruang sampel suatu percobaan".

Pada kegiatan inti ini, selanjutnya guru memberikan penjelasan materi tentang menentukan peluang suatu kejadian sederhana pada suatu soal yang berbentuk cerita. Disela-sela penjelasan guru tidak lupa untuk memberi motivasi dan memberikan kesempatan kepada siswa untuk bertanya dan berpendapat. Kemudian guru meminta siswa duduk secara berkelompok sesuai dengan kelompoknya masing-masing untuk menyelesaikan permasalahan yang ada dalam LKS yang akan diberikan.

Guru memantau/mengamati kerja setiap kelompok serta membimbing kelompok yang mengalami kesulitan. Selanjutnya guru mempersilahkan kepada perwakilan setiap kelompok untuk mengerjakan soal latihan tersebut di papan tulis. Di akhir pembelajaran guru bersama siswa menyimpulkan jawaban yang tepat sehingga semua siswa dapat mengetahui jawaban yang tepat.

Selama proses pembelajaran berlangsung, peneliti dan teman sejawat mengobservasi jalannya pembelajaran dengan menggunakan lembar observasi untuk guru dan siswa.

\section{Observasi dan Evaluasi}

Pada siklus II ini, pembelajaran dilakukan dalam 1 kali pertemuan yang memuat 4 jam pelajaran dengan pendekatan kontekstual yang diterapkan dalam kelompok-kelompok. Dengan cara ini pembelajaran menjadi lebih bermakna dan dapat meningkatkan kemampuan pemecahan masalah matematis siswa kelas IX-C SMP Mahardhik Batujajar.

\section{Observasi}

Berdasarkan hasil lembar observasi aktivitas guru, ketuntasan hasil observasi guru pada proses pembelajaran mencapai $86,15 \%$. Hasil observasi kemampuan guru mengelola pembelajaran ini meningkat sebesar sekitar $16 \%$ dari siklus I. Hal ini menunjukkan bahwa indikator kinerja dari segi proses telah tercapai yaitu minimal $75 \%$ proses pelaksanaan tindakan dilaksanakan sesuai dengan rencana perbaikan pelaksanaan pembelajaran yang ditetapkan.

Sementara itu, berdasarkan hasil lembar observasi aktivitas siswa, secara umum ketuntasan hasil observasi akitivitas siswa pada proses pembelajaran yang dilakukan guru pada siklus kedua sudah mencapai $78 \%$. Hasil observasi siswa ini meningkat sebesar 20\% dari siklus I. Hal ini menunjukkan bahwa indikator kinerja dari segi proses telah tercapai yaitu minimal $75 \%$ proses pelaksanaan tindakan dilaksanakan sesuai dengan rencana perbaikan pembelajaran yang ditetapkan.

\section{Evaluasi}

Pada siklus II ini, pembelajaran dilakukan selama 4 jam pelajaran (2 pertemuan) untuk menyelesaikan kompetensi dasar "menentukan peluang suatu kejadian sederhana" yang merupakan penjabaran dari standar kompetensi "memahami peluang kejadian sederhana". Rangkaian selanjutnya pada tindakan ini adalah memberikan evaluasi atau tes siklus II yang dilaksanakan pada hari Rabu, 22 November 2017. Tes ini bertujuan untuk mengetahui sejauh mana kemampuan pemecahan masalah matematis siswa pada materi peluang setelah dilakukan pembelajaran dengan pendekatan kontekstual. Selain itu, evaluasi ini juga 
dilakukan untuk mengetahui apakah pelaksanaantindakan siklus II lebih baik atau mengalami peningkatan dari pelaksanaan tindakan siklus II.

Dari pengamatan yang dilakukan peneliti, hasil pelaksanaan tindakan siklus II dapat dilihat dari dua segi yaitu: Pertama, dari segi proses pelaksanaan skenario pembelajaran oleh guru yang telah mencapai rata-rata ketuntasan skenario pembelajaran yaitu mencapai $86,15 \%$. Kedua, dari segi hasil tes siklus II yang telah mencapai kriteria ketuntasan minimal yaitu 75, seperti yang terlihat pada tabel 2 .

Tabel 2. Hasil Analisis Ketuntasan Belajar pada Pembelajaran Siklus II

\begin{tabular}{llcc}
\hline No. & Ketuntasan & Jumlah & Persentase (\%) \\
\hline $1 . \quad$ Tuntas & 27 & $84,37 \%$ \\
\hline 2. & Tidak tuntas & 5 & $15,63 \%$ \\
\hline Jumlah siswa & 32 & \\
\hline Rata-rata nilai & 77,35 & 100 \\
\hline \multicolumn{2}{l}{ Persentasi Ketuntasan } & & \\
\hline
\end{tabular}

Hasil tes tindakan siklus II menunjukkan bahwa kemampuan pemecahan masalah matematis pada materi peluang telah mencapai 84,37\% atau sebanyak 27 dari 32 siswa memperoleh nilai diatas 75 dengan niali rata-rata 77,35. Mengacu pada indikator kinerja penelitian ini, dapat disimpulkan sudah tercapai.

\section{Refleksi}

Kegiatan refleksi pada siklus II ini, menunjukkan hasil yang memuaskan, baik bagi guru maupun peneliti. Hasil observasi yang dilakukan peneliti menunjukkan bahwa pembelajaran dengan menggunakan pendekatan kontekstual yang diterapkan di kelas IX-C SMP Mahardhika Batujajar memberikan hasil yang sangat baik.

Selain itu, telah ada peningkatan jumlah siswa yang mampu menyampaikan pendapatnya dalam diskusi kelas walaupun hanya sedikit dan mendapat bimbingan dari guru. Banyak siswa lebih aktif dalam menjelaskan kembali pengetahuan yang telah diperolehnya, bertanya, mengemukakan pendapat dalam kelompoknya, dan dapat menyimpulkan materi. Secara umum, kelemahan pada pelaksanaan tindakan siklus I telah diperbaiki pada siklus II ini. Walaupun masih ada siswa yang tidak fokus dalam pembelajaran, namun hal itu tidak mengganggu proses pembelajaran.

Walaupun demikian tentu masih terdapat beberapa kekurangan didalam pelaksanaan tindakan siklus II ini, diantaranya masih ada sebagian kecil siswa yang tidak memperhatikan penjelasan guru dan tidak aktif belajar dalam kelompok masing-masing. Disamping itu, guru harus lebih memotivasi siswa agar mereka lebih berani mengemukakan pendapatnya dan lebih menghargai pendapat orang lain.Sesuai dengan rencana tindakan yang tercantum dalam RPP dan berdasarkan pada tercapainya indikator kinerja, maka penelitian ini dilaksanakan sampai pada siklus II. 


\section{Pembahasan}

Penelitian tindakan kelas ini terdiri dari 2 siklus. Siklus I terdiri dari 1 kali pertemuan (4 jam pelajaran) dan siklus II terdiri dari 1 kali pertemuan (4 jam pelajaran) yang dilaksanakan sesuai dengan prosedur penelitian.

Berdasarkan observasi pelaksanaan pembelajaran matematika pada materi menentukan ruang sampel pada suatu kejadian untuk siklus I, menunjukkan bahwa pembelajaran dengan pendekatan kontekstual belum sempurna dilaksanakan sesuai dengan rencana pelaksanaan pembelajaran yang telah dibuat. Dalam pembelajaran ini juga peneliti mengamati perkembangan siswa. Secara umum untuk siklus I terdapat beberapa kekurangan yaitu tidak semua siswa aktif dalam diskusi kelompoknya, sedikit mengemukakan pendapat dan masih banyak kelompok yang tidak memperhatikan petunjuk yang terdapat dalam LKS.

Hasil evaluasi tindakan siklus I yang di peroleh adalah sebesar 50\% atau sebanyak 15 siswa yang memperoleh nilai $\geq 75$ dengan nilai rata-rata 55,16 . Hasil evaluasi yang diperoleh siswa di atas belum mencapai indikator kemampuan pemecahan masalah matematis yang ditetapkan. Ada beberapa item yang peneliti anggap sebagai sebab tidak tercapainya hasil yang diinginkan, bahwa pada siklus I ini ada beberapa poin yang kurang maksimal atau bahkan tidak dilakukan oleh guru dan hal tersebut merupakan inti atau pokok dari pembelajaran dengan menggunakan pendekatan kontekstual yaitu salah satunya bimbingan guru kurang maksimal. Ketuntasan dari segi proses pelaksanaan pembelajaran yang dilakukan guru dan siswa hanya mencapai 70,76\%.

Berdasarkan hasil observasi pada pelaksanaan tindakan untuk siklus II yang menerapkan pembelajaran menggunakan pendekatan kontekstual ini sudah lebih baik dari sebelumnya. Guru terus berupaya memperbaiki kelemahan yang ditemui dalam pelaksanaan tindakan siklus I. Sementara itu, hasil observasi terhadap siswa secara umum menunjukkan bahwa siswa lebih aktif dalam belajar, bertanya, dan berdiskusi dengan rekannya di dalam kelompok, antar kelompok, dan kepada guru. Hal ini sangat positif dalam memacu upaya meningkatkan kemampuan pemecahan masalah matematis terhadap hasil belajar siswa pada materi peluang.

Berdasarkan hasil evaluasi tindakan siklus II, menunjukan peningkatan hasil belajar siswa bila dibandingkan dengan hasil evaluasi tindakan siklus I. Dari 32 siswa yang hadir yang mampu memperoleh nilai $\geq 75$ mencapai $84,37 \%$ atau sebanyak 27 siswa dengan nilai rata-rata sebesar 77,35. Hal ini menunjukkan adanya peningkatan dari 50\% siswa tuntas pada siklus 1 dan $84,37 \%$ siswa tuntas pada siklus II, yang berarti bahwa ada peningkatan sekitar $34 \%$ atau sebanyak 12 siswa dari hasil evaluasi tindakan siklus I. Dengan demikian siswa yang mampu menunjukkan kemampuan pemecahan masalah matematis pada materi peluang semakin bertambah dibandingkan dengan evaluasi siklus I. Dengan kata lain, hasil evaluasi siklus II menunjukkan bahwa kemampuan pemecahan masalah matematis siswa mengalami peningkatan bila dibandingkan dengan evaluasi siklus I.

\section{KESIMPULAN}

Pada siklus I secara klasikal mendapatkan nilai rata-rata sebesar 55,16, kurang dari pencapaian KKM sekolah. Sedangkan, pada siklus kedua skor kemampuan pemecahan masalah matematis siswa secara klasikal mengalami peningkatan yang signifikan, yaitu mencapai nilai rata-rata sebesar 77,35. Jika dikaji dari sisi ketuntasan, pada siklus pertama hanya 15 siswa yang mencapai nilai KKM dari 30 siswa. Pada siklus kedua terjadi peningkatan yang signifikan, yaitu terdapat 27 siswa dari 32 siswa yang mencapai nilai KKM. 
Berdasarkan hasil tersebut, dapat disimpulkan bahwa dari siklus pertama ke siklus kedua terjadi peningkatan kemampuan pemecahan masalah matematis siswa baik dilihat dari nilai secara individu maupun klasikal. Hal ini merujuk pada kesimpulan bahwa penerapan pendekatan pembelajaran kontekstual seperti yang dilakukan pada penelitian ini dapat meningkatkan kemampuan pemecahan masalah siswa pada mata pelajaran matematika.

\section{DAFTAR PUSTAKA}

Dahlia, B., Tandiling, E., \& Suratman, D. (2016). Peningkatan Kemampuan Pemecahan Masalah Matematis Menggunakan Pendekatan Saintifik dan Pendekatan CTL. Jurnal Pendidikan dan Pembelajaran, 5(9).

Hendriana, H., Rohaeti, E.E., \& Sumarmo, U. (2017). Hard Skills dan Soft Skills Matematik Siswa. Bandung: Refika Aditama.

Hendriana, H., \& Afrilianto, M. (2017). Langkah Praktis Penelitian Tindakan Kelas bagi Guru. Bandung: Refika Aditama.

Hidayat, W., \& Sariningsih, R. (2018). Kemampuan Pemecahan Masalah Matematis dan Adversity Quotient Siswa SMP Melalui Pembelajaran Open Ended. JNPM (Jurnal Nasional Pendidikan Matematika), 2(1), 109-118.

Mawaddah, S., Anisah, H. (2015). Kemampuan Pemecahan Masalah Matematis Siswa pada Pembelajaran Matematika dengan Menggunakan Model Pembelajaran Generatif di SMP. Jurnal Pendidikan Matematika, 3(2).

Minarni, A. (2012). P - 10 pengaruh pembelajaran berbasis masalah terhadap kemampuan pemecahan masalah matematis, (November), 978-979.

Mulhamah., Putrawangsa, S. (2016). Penerapan Pembelajaran Kontekstual dalam Meningkatkan Kemampuan Pemecahan Masalah Matematis. Jurnal Pendidikan Matematika, 10(1).

Syazali, M. (2015). Pengaruh Model Pembelajaran Creative Problem Solving berbantuan Media Maple 11 terhadap Kemampuan Pemecahan Masalah Matematis. Jurnal Pendidikan Matematika, 6(1). 
228 Monica, Afrilianto, \& Rohaeti, Kemampuan Pemecahan Masalah Matematis Siswa SMP 